\title{
SECURITIES LAW DUTIES OF BOND COUNSEL
}

\section{Richard JoHNSON* AND ROBERT H. WHEELER*}

There has been considerable interest recently in disclosure requirements for the sale of state and local government securities. The severe financial distress experienced by New York City and its consequent failure to pay certam of its obligations as they became due have focused particular attention on municipal bond disclosure matters. ${ }^{1}$ Charges have been made that New York City engaged for years in financial flim-flam, and that its true financial picture was hidden from the investing public. ${ }^{2}$ In recent months, the Securities and Exchange

* Partner, Isham, Lincoln \& Beale, Chicago, Illinois; A.B. 1962, Ripon College; J.D. 1965, University of Chicago.

** Associate, Isham, Lincoln \& Beale, Chicago, Illinois; B.A. 1967, St. Mary's College; J.D. 1970, Northwestern University.

The authors wish to express appreciation to Mr. Steven Gilford for his contributions to this Article, especially with respect to the application of the recklessness standard of libel law to rule $10 \mathrm{~b}-5$.

[AUTHORS' Note: Since the completion of this Article, Franke v. Midwestern Oklahoma Dev. Authority, [1976-1977 Transfer Binder] CCH FED. SEC. L. REP. I 95,786 (W.D. Okla. 1976), has been decided, bearing out the observation of the authors that bond counsel issuing the legal opinion only with respect to legality of bond obligations and the tax-exempt status of the bonds has no responsibility under the federal securities laws for the accuracy of the offering circular. The court made its ruling on a motion for summary judgment and denied plaintiff's claim that bond counsel had either directly violated rule $10 \mathrm{~b}-5$ or aided and abetted a violation by other parties.]

THE FOLLOWING CITATIONS WILL BE USED IN THIS ARTICLE:

Securities Act of 1933, 15 U.S.C. $\S \S 77 a-a a ~(1970)$ [hereinafter cited as 1933 Act];

Securities Exchange Act of 1934, 15 U.S.C. $\$ \S 78$ a-jj (1970) [hereinafter cited as 1934 Act];

Securities Acts Amendments of 1975, Pub. L. No. 94-29, 89 Stat. 97 (June 4, 1975) [hereinafter cited as Securities Reform Act of 1975];

Securities Exchange Act Rule 10b-5, 17 C.F.R. $\$ 240.10 b-5$ (1976) [hereinafter cited as Rule 10b-5].

1. The New York situation has been described generally in CONGRESSIONAL BUDGET Office, New York City's Fiscal Problem: Its Origins, Potential Repercussions, and Some Alternative Policy Responses (Background Paper No. 1, Oct. 10, 1975), reprinted in full, Hearings on S. 1833, S. 1862, S. 2372, S. 2514 and S. 2523, New York City Financial Crisis Before the Sen. Comm. on Banking, Housing and Urban Affairs, 94th Cong., 1st Sess. 509-48 (1975); JoINT ECONomic CoMM., 94TH Cong., 1sT SEss., NEW YoRk CITY's FinanCIal CRISIS: AN Evaluation of ITS ECONOMIC IMPACT AND OF Proposed Policy Solutions (Comm. Print 1975); Shalala \& Bellamy, A State Saves a City: The New York Case, 1976 DUKe L.J. 1119.

2. A detailed discussion of problems in New York City's budgeting system can be found in Robertson \& Vecchio, A Legal History of Expense Budgeting in New York 
Commission has undertaken an investigation into sales of New York City's obligations, an investigation which the City has sued to curtail on constitutional grounds. ${ }^{3}$

Legislation has been introduced in both the Senate and the House (but not adopted in either clramber) to require substantial issuers of municipal bonds to file extensive disclosure statements prior to issuing securities. ${ }^{4}$ In response to the public concern in this area, the Mumcipal Finance Officers Association has distributed, in draft form, suggested disclosure standards for use by municipal issuers. ${ }^{5}$

This increased interest in full disclosure in inunicipal bond issues has focused new attention on the role of bond counsel. Certain SEC officials and some courts have expressed the view that discipline of lawyers holds a key to prevention of many securities misdeeds. ${ }^{6}$ Thus, it is not surprising that questions have been raised about bond counsel's responsibility for disclosure. Bond counsel have, in fact, been included as defendants in several recent SEC enforcement proceedings. ${ }^{7}$ Bond counsel have begun to consider whether they may be required by federal law to undertake a "due diligence" type examination ${ }^{8}$ to insure that there is proper disclosure of all material facts in bond issues for which they give an approvimg opinion. In light of this concern, this Article will consider the historical role of bond counsel, the possible legal bases for imposition of securities law responsibilities, and some of the practical problems which bond counsel are likely to face in this regard.

City, 4 Fordham Urban L.J. 1 (1975). See also Lodal, Improving Local Government Financial Information Systems, 1976 DUKE L.J. 1133.

3. City of New York v. SEC, CCH FED. SEC. L. REP. \ 95,667 (S.D.N.Y. 1976) (complaint). The issues in New York v. SEC are thoroughly discussed in Comment, Federal Regulation of Municipal Securities: A Constitutional and Statutory Analysis, 1976 DUKE L.J. 1261, 1310. A similar suit, also challenging the constitutionality of federal investigation of local governmental securities dealings, has been filed by the City of Philadelphia. THE WeEKLY BOND BUYER, Aug. 9, 1976, at 1.

4. S. 2969, S. 2574, 94th Cong., 2d Sess. (1975); H.R. 15205, 94th Cong., 2d Sess. (1975).

5. Municipal Finance Officers Ass'n, Disclosure Guidelines for Offerings of Securmites by State and Local Governments (Exposure Draft, Nov. 10, 1975). A revised version of the disclosure guidelines will be published by the M.F.O.A. in January, 1977. 51 Municipal Finance OfFicers Ass'N Newsletter 101 (1976).

6. See, e.g., SEC v. Spectrum, Ltd., 489 F.2d 535, $541-42$ (2d Cir. 1973); Address by SEC Commissioner A.A. Sommer, Jr., "The Emerging Responsibilities of the Securities Lawyer," [1973-1974 Transfer Binder] CCH FED. SEC. L. REP. II 79,631 (January, 1974).

7. SEC v. Astro Prod. of Kansas, Inc., SEC Litigation Release No. 7557 (Sept. 13, 1976); SEC v. Reclamation Dist. No. 2090, SEC Litigation Release No. 7460 (June 22, 1976); SEC v. Ferguson, Securities Act of 1933 Release No. 5523 (Aug. 21, 1974). For a discussion of these cases, see text accompanying notes 114-19 infra.

8. See notes $37-45$ infra and accompanying text. 


\section{The Role of Bond Counsel}

The issuance of state and local governmental obligations is customarily accompanied by a favorable legal opinion of an individual or firm expert in mumicipal finance law, known as a bond counsel. It is, in fact, uncommon for any but very small issues of nunicipal bonds not to be acconipanied by such an opinion. The role played by bond counsel is, however, frequently not fully understood. The services historically performed by bond counsel have differed considerably from the services of counsel in corporate fimancings. An understanding of the role of bond counsel is therefore essential to a consideration of the bond counsel's obligations under federal securities laws.

The unique character of the bond counsel's role derives from historical practice. Nineteenth century abuses in the incurring of local government debt led many states to impose stringent constitutional and statutory limitations on the power to incur governmental debt. ${ }^{9}$ In a number of instances, courts actually reheved issuers from their obligations with regard to. improperly issued bonds by declaring the bonds void. ${ }^{10}$

To protect against the unsettling possibility of purchasing void obligations, it became the practice for potential purchasers of mumicipal bonds to submit a copy of a transcript of the issuer's proceedings concerning the-bonds to an expert in municipal law for an opmion as to the binding character of the bonds. ${ }^{11}$ This "bond counsel" served essentially as an independent legal expert-not as the regular counsel for any of the parties to the transaction. The bond counsel's opinion was based on a review of the transcript and was limited to the validity of the debt instruments. ${ }^{12}$

\section{The Scope of Representation}

The current role of bond counsel still reflects these historical ante-

9. For a classic examination of the early history of state and local debt and the needed development of debt limitations, see B. RATchFord, AMERICaN STATE DEBTS (1941). An overview of current state constitutional and statutory debt limitations is presented in U.S. ADVISORY COMMISSION ON INTERGOVERNMENTAL RELATIONS, UNDERSTANDING THE MARKET FOR STATE AND LOCAL DEBT 44-53 (1976). There are probleins with these limitatious, and their efficacy has been questioned. See sources cited in Blaydon \& Gilford, Financing the Cities: An lssue Agenda, 1976 DUKE L.J. 1057, 1088 n.127.

10. See 15 E. McQuilin, The Law of Municipal Corporations $\S 43.28$ (3d ed. rev. 1970). See generally B. RATCHFord, supra note 9.

11. See generally Guaudolo, Municipal Bond Counsel, in JoINT EConomi Comm., 89th Cong., 2d Sess., 2 State and local Public Facility NeEds and Financing: Public Faciurty Financing 207 (H. Comm. Print 1966).

12. L. Chermak, The LaW of Revenue Bonds 63-67 (1954). 
cedents. In most instances, bond counsel does not serve as a lawyer with overall transactional responsibility for any party. Rather, the bond counsel serves as a special counsel for the limited purpose of rendering an opinion as to the validity and tax-exempt character of the securities. ${ }^{13}$

The situation is, of course, seldom this straightforward. Most commonly, the bond counsel is retained by the issuer. ${ }^{14}$ Counsel customarily determines what matters must be mcluded in the transcript and usually prepares a number of the more important of the transcript documents. ${ }^{16}$ In some cases, bond counsel may also provide the issuer with advice on financing alternatives and requirements. Each of these activities arises from the requirements of giving an approving legal opinion.

Sometimes, especially in negotiated sales of revenue bonds, bond counsel is retained not by the issuer but by an underwriter. In this situation, bond counsel may also serve as the underwriter's counsel with regard to all aspects of a bond transaction. ${ }^{16}$

\section{The Opinion}

The nature of the opinion rendered by bond counsel is also derived from historical practice. In general, the legal opinion is closely tailored to a well-established form, narrow in scope and restricted as to basis. The typical opinion states that the counsel has examined a certified copy of the transcript of proceedings authorizing the bonds as well as one of the executed bonds, and that, based on this examination, the lawyer is of the opinion that the securities are legal and binding obligations of the issuer. Where appropriate, the opinion will also designate any specific funds that have been pledged and state that interest on the obligations is presently exempt from federal incoine taxes.

13. Even within the bond counsel community, attorneys differ as to who is the bond counsel's client. Some hold that the client is the holder of the bonds, who presumably relies on the bond counsel's opinion in acquiring the bonds. Probably the more realistic and accurate view, however, is that the client is the party who retains and pays for the bond counsel's services.

14. See generally Guandolo, supra note 11, at 213.

15. The transcript in a municipal bond transaction generally includes copies of the bond proceedings, resolutions, ordinances, and election documents, if any, as well as certificates as to various facts. See Guandolo, supra note 11, at 209. In order to assure the satisfaction of legal requirements, bond counsel may draft the needed resolutions, ordinances, election documents and certificates for the issuer.

16. As will be seen, to the exlent that bond counsel perform services beyond those direclly related to their opinion-giving function, they will tend to encounter more difficult praclical problems of securities law responsibility. See text accompanying notes 114-24 infra. 
Bond counsel's opinion contrasts sharply with the customary legal opinion rendered in regulated sales of corporate securities. As noted previously, the opinion rendered on a nuunicipal security is explicitly confined to an examination of the issuer's record of proceedings. This record consists of certified copies of the minutes and resolutions of the issuing governinental body-such as a city council-and of certificates as to various facts prepared by public officers. In contrast, legal opinions in corporate issues nray state that they are "based upon such documents, records and matters of law as [counsel] have considered to be relevant." 17 Unlike their corporate colleagues, bond counsel do not represent that they have gone beyond a formal review of the documents.

Not only is bond counsel's legal opinion narrowly based, its reach is also typically narrow. The scope of the opinion is normally limited to the legal validity of the obligations, the bondholders' claim upon funds pledged to their payment and the tax-exempt status of the bonds. Unlike the practice of many corporate counsel, bond counsel rarely participate in the drafting of the official statement (the sales document in municipal bond issues which perfornis roughly the same function as the offering circular and prospectus in issues of corporate securities), and their opinions do not normally cover the accuracy or completeness of the representations in the official statement. ${ }^{18}$ Again, this contrasts with the typical corporate opinion which may state that the form of the registration statement complies with statutory requirements and SEC rules and that, based upon conferences with the company's representatives, counsel does not believe that the prospectus contains any untrue statement of a material fact or omits any material fact necessary to make the prospectus not nisleading. ${ }^{19}$

The role of bond counsel is therefore a limited one in most nuunicipal bond transactions. Bond counsel do not represent parties to the transaction generally. Their opinion is based primarily on a transcript review and is narrowly drawn, covering only the validity of the security.

17. For other illustrative statements of the scope of the legal opinion in corporate offerings, see Cheek, Potential Liability of Counsel Named in a Prospectus, reprinted in Securities Law ReviEw-1973 at 203, 210-11 (E. Folk ed.).

18. For tax-exempt industrial development bonds, bond counsel's legal opinion varies somewhat from the standard model. See notes 26-28 infra and accompanying text. Here, the bond counsel's opinion may be somewhat more extensive. The bond counsel may opine that the bonds are exempt from registration requirements under the 1933 Act. See note 47 infra. Bond counsel may also opine as to the accuracy of those portions of the offering circular which describe the bonds and the principal documents securing the bonds.

19. For a general discussion of the lawyer's opinion used in a typical SEC registered corporate security, see Cheek, supra note 17, at 207-15. 
Unlike their corporate colleagues, bond counsel do not usually prepare the prospectus or opine as to its accuracy or completeness.

\section{Involvement of Other Counsel}

Given the limited role of bond counsel, it may seem surprising that the bond counsel's opmion is the only legal opinion which is delivered in many municipal issues. The issuer's regular attorney usually participates in the transaction and, for revenue bonds, may opine on title and other questions concerning security for the bonds. ${ }^{20}$ But the issuer's counsel does not normally express any opinion as to the official statement's accuracy or sufficiency or as to the validity of the bonds. ${ }^{21}$

Moreover, in the majority of municipal bond issues (other than for the industrial development revenue type of bonds), underwriters are not represented by outside counsel. ${ }^{22}$ Presumably, the very low rate of mumicipal defaults, ${ }^{23}$ the fact that mumcipal bond underwriters have not frequently been the targets of securities litigation, and the comparatively smaller profit spread in municipal issues ${ }^{24}$ all lead underwriters to avoid the expense of outside counsel. While it is currently becoming somewhat more common for underwriters to obtain counsel in larger negotiated bond sales, this practice still remains less common than might be supposed. ${ }^{25}$

It should be noted, however, that there is usually no lack of legal representation in municipal issues involving industrial development rev-

20. See generally L. CHERMAK, supra note 12 , at 63 .

21. This is presumably because lawyers specializing in general municipal law are not usually regarded as having sufficient expertise in this area. Bond counsel expertise is concentrated in a relatively few law firms. In general, such firms are large and are clustered in regional financial centers. See Guandolo, supra note 11, at 214-16; DiRectory of Municipal Bond DEAlers of THE UNITED States (rev. ed. 1971).

22. It is not uncommon for underwriters to have staff counsel look over offering circulars, but their counsel does not typically undertake the kind of due diligence examination which would be conducted in a registered offering.

23. See J. Maxweld, Financing State and Local Governments 184-85 (1969); U.S. AdVISORY COMMISSION ON INTERGOVERNMENTAL RELATIONS, supra note 9, at 23-27. In the early $1970 \mathrm{~s}$, less than $0.4 \%$ of the total outstanding municipal indebtedness was in default.

24. See J. MAXwelL, supra note 23, at 190-92.

25. While some may be surprised at the absence of legal opinions on securities law matters in such transactions, it may, in fact, make perfectly good sense in the majority of cases. In most public purpose (i.e., non-industrial development) municipal issues, the expertise of a lawyer is needed primarily for ascertaining the bond's validity. The financial consultant or underwriter may well be more knowledgeable about those matters which require disclosure. Given the very low rate of default in such municipal obligations, see note 23 supra, one nay fairly question whether the extensive cost, borne by the taxpayers, of having counsel examine official statements for accuracy or completeness in thousands of smaller bond issues would in fact be worth the possible return in preventing investor loss. See also note 121 infra. 
enue bonds. ${ }^{26}$ These are bonds issued by a governmental unit to finance a non-governinental project such as an industrial pollution control facility. Such bonds are payable, not from public funds, but from revenues derived froin the coinpany or institution for which the proceeds are utilized. ${ }^{27}$ Here, in addition to bond counsel, lawyers for the issuer, the underlying obligor (the company or institution which is to provide the revenues) and the underwriters are all actively imvolved. Because the security for these bonds depends not on the credit of the issuer but on the credit of the private underlying obligor and because of the obvious analogy to registered securities, underwriters generally find it prudent to undertake a due diligence investigation and to employ expert counsel on their behalf in these transactions. ${ }^{28}$

\section{THE STATUTORY FramewORK OF THE Federal Securities Laws}

The fact that bond counsel nay be the only lawyers rendering any legal opinion in many municipal bond issues suggests the question of whether bond counsel are responsible, notwithstanding the limited nature of their services, for examining the accuracy and completeness of the representations in the selling documents. Obviously, the starting point for such consideration is the text of the federal securities laws. While municipal bond issues are generally exempt from all but the basic anti-fraud sections of the Securities Act of 1933 and the Securities Exchange Act of 1934, the regulatory franework established by these acts is instructive in considering the obligations of bond counsel.

26. See generally Albritton v. City of Winona, 181 Miss. 75, 178 So. 799, appeal dismissed, 303 U.S. 627 (1938); Mitchell v. North Carolina Indus. Dev. Fin. Authority, 273 N.C. 137, 159 S.E.2d 745 (1968); L. MOAK \& A. HILlHouse, CONCEPTS AND Practices in Local Government Finance 261-65 (1975); Investment Bankers Ass'n, Industrial Plants Financed and Owned by Local Governments, in JOINT EcoNoMIC Comm., 89th Cong., 2D Sess., 1 State and Local Public Facility NeEds and Financing: Public Facility NeEds 690-93 (1966); Pinsky, State Constitutional Limitations on Public Industrial Financing: An Historical and Economic Approach, $111 \mathrm{U}$. PA. L. REV. 265 (1963).

27. Section 103 (c) of the Internal Revenue Code restricts the scope of the tax exemption granted for these bonds. INT. REv. CODE of 1954, $\$ 103$ (c). In addition to its direct financial importance to the underlying obligor, the tax exemption has important securities law significance, since industrial development bonds are normally exempt from the registration requirements of the Securities Act of 1933 only if they are exempt from the federal income tax under section 103(c). 1933 Act $\$ 3(\mathrm{a})(2), 15$ U.S.C. $\$$ $77 \mathrm{c}(\mathrm{a})(2)$ (1970). See note 47 infra.

28. In some limited instances, section 12 of the 1933 Act, 15 U.S.C. $\$ 771$ (1970), may also be relevant in causing underwriters of industrial development issues to exercise due diligence. See note 47 infra. Also, see notes 35, $42-44$ infra and accompanying text on the operation of section 12 and its due diligence requirement. 


\section{The 1933 Act}

The Securities Act of 1933 imposes substantial duties of full and fair disclosure on certain persons in connection with the issuance of regulated securities. This is accomplished principally by its registration statement and prospectus requirements. ${ }^{29}$ Under both statute and rule, the prospectus and the registration statement must contain detailed information about the issuer which is likely to be relevant to an investment decision. ${ }^{30}$

The 1933 Act also provides for a carefully arranged pattern of civil remedies and penalties to protect the investor's right to disclosures which are not misleading. Section 11 of the Act ${ }^{31}$ imposes strict liability on issuers of non-exempt securities ${ }^{32}$ for material untruths in the registration statement, for failure to disclose certain required material facts, and for failure to disclose matters which are necessary to make the representations not misleading. Section 11 liability may also be imposed on underwriters of such securities and on certain company officers and directors or persons controlling the underwriter or the issuer. ${ }^{33}$ Under certain circumstances, experts named with their consent in the registration statement are also subject to section 11 liability as to matters within their area of expertise. ${ }^{34}$ In addition, section 12(2)

29. 1933 Act $\$ 5,15$ U.S.C. $\$ 77$ (1970).

30. The requirements concerning amount and type of information to be included in registration statements were initially established by the 1933 Act. See 1933 Act $\S 7,15$ U.S.C. $\$ 77 \mathrm{~g}(1970)$ (registration statement); Schedules $\mathrm{A}$ and B, 15 U.S.C. \& 77aa (1970) (schedule of information for registration statement); 1933 Act $\$ 10,15$ U.S.C. $\S$ 77j (1970) (prospectus). Sections 7 and 10 (c) also authorized the SEC to require additional information in the registration statement and the prospectus by rule. This has been done in SEC Regulation C, art. 1-2, Rules 400-494, 17 C.F.R. $\$ \$ 230.400-.494$ (1976), governing the requirements for registration statements and prospectuses.

31. 1933 Act $\S 11,15$ U.S.C. $\$ 77 \mathrm{k}(1970)$. Since the purpose of this portion of the Article is only to describe the federal regulatory scheme generally, as it may be instructive for bond counsel, no detailed discussion of the precise scope and exact limitations of this right to recover is appropriate. It should be emphasized that the liability provisions of section 11 are sophisticated; they represent careful congressional compromise and do not yield to simplifications. See H.R. REP. No. 152, 73d Cong., 1st Sess. 26-27 (Conference Report 1933). Compare S. ReP. No. 47, 73d Cong., Ist Sess. 4-6 (1933), with H.R. No. 85, 73d Cong., 1st Sess. 9-10 (1933). A more detailed discussion of the scope of purchasers' rights under section 11 may be found in Folk, Civil Liabilities Under the Federal Securities Acts: The BarChris Case, 55 VA. L. Rev. 1 (1969).

32. Section 3(a) of the 1933 Act, 15 U.S.C. $\$ 77 \mathrm{c}(\mathrm{a})$ (1970), exempts certain securities from the registration and prospectus requirements of the 1933 Act. See notes 46-47 infra and accompanying text for a discussion of the exemption for municipal bonds. See also 1933 Act $\$ 4,15$ U.S.C. $\$ 77 \mathrm{~d}$ (1970) (exempting certain transactions).

33. 1933 Act $\$ \$ 11(a), 15,15$ U.S.C. $\$ \$ 77 \mathrm{k}(\mathrm{a}), 770$ (1970).

34. 1933 Act $\S 11(\mathrm{a})(4), 15$ U.S.C. $\$ 77 \mathrm{k}(\mathrm{a})(4)(1970)$. In part, those who may 
imposes civil liability for offers or sales of securities made pursuant to a prospectus or oral communication which is false or contains material omissions. ${ }^{35}$ While section 11 applies to certain specifically stated persons, section 12 applies only to "sellers."

\section{Due Diligence and the Statutory Liability of Lawyers}

Sections 11 and 12 establish so-called "due diligence" defenses to the liability of persons other than the issuer (who under section 11 is an absolute guarantor of the material accuracy of the registration statement). ${ }^{37}$ The precise language of the defense is important. Under section 11, such a defendant is not liable as to most matters if it is shown that the defendant "after reasonable investigation, had reasonable ground to believe, and did believe," that the challenged statements in the registration statement were true and that no material omission was made ${ }^{38}$ The standard is different, however, as to representations expertised by others or statements which purport to be made by public officials or to be copied or extracted from an official public document. $^{39}$ In these cases, there is no requirement of "reasonable investigation." Rather, the defendant need only show that "he had no reasonable grounds to believe and did not believe" that the representations were untrue or misleading because of a material omission, ${ }^{40}$ or, in the case of an official document, that the material was not fairly presented. ${ }^{41}$

This distinction between types of due diligence defenses under section 11 is important to an understanding of bond counsel's securities

be liable for the accuracy of the registration statement are determined by 1933 Act $\S 6$, 15 U.S.C. $\$ 77 \mathrm{f}(1970)$, which identifies specific parties, including the issuer and its chief financial and executive officers, who must sign the registration statement.

35. 15 U.S.C. $\& 77 l(2)(1970)$.

36. See note 43 infra and accompanying text.

37. Section 11 of the 1933 Act makes its due diligence defenses available to any person "other than the issuer." 1933 Act $\S 11(\mathrm{~b}), 15$ U.S.C. $\$ 77 \mathrm{k}(\mathrm{b})$ (1970). The issuer is therefore strictly liable for any injury caused by a material misstatement or omission in the registration statement.

A due diligence defense is available to the issuer under section 12 , however, which provides that a seller can avoid liability by proving "that he did not know, and in the exercise of reasonable care could uot have known, of such untruth or omission." 15 U.S.C. $\$ 77 l(2)$ (1970). Nevertheless, it should be noted that in many cases the issuer can be held strictly liable for misstatements or omissions in the prospectus since the bulk of its information will also be included in the registration statement. See 1933 Act $\$ 7$, Schedule A, 15 U.S.C. $\$ \$ 77 g, 77 a a$ (1970).

38. 1933 Act $\$ 11$ (b)(3)(A), 15 U.S.C. $\$ 77 \mathrm{k}(\mathrm{b})(3)(A)(1970)$.

39. See 1933 Act $\S \S 11(\mathrm{~b})(3)(B)-(D), 15$ U.S.C. $\$ \S 77 \mathrm{k}(\mathrm{b})(3)(B)-(D)$ (1970).

40. Id.

41. See 1933 Act $\$ 11(b)(3)(D), 15$ U.S.C. $\S 77 \mathrm{k}(\mathrm{b})(3)(\mathrm{D})$ (1970). 
law responsibilities. In the case of public documents and statements made by public officials, there is no requirement of a reasonable investigation in order to establish the defense. Rather, there is only the requirement that one not have reason to believe that the representation in question is false. Since the typical bond counsel opinion is based on public official documents and statements which give rise to a lesser duty of care under the section 11 due diligence defense, it would be highly surprising were the provision of the 1933 Act used, by analogy, to require bond counsel to conduct a further "reasonable investigation." Where Congress wished to impose duties of investigation as a condition of a defense, it did so in an express and limited fashion. Its failure to impose such duties with respect to public official documents is therefore relevant in considering the duties of bond counsel.

The "due diligence" defense under section 12(2) is phrased somewhat differently. To establish the defense here, the burden is on the seller to show that it did not know and "in the exercise of reasonable care could not have known of the untruth or omission." 42 Section 12 should not pose a substantial threat of liability to counsel since it imposes liability only on the seller of a security. Under current case law, a lawyer who does nothing more than perform legal services is not a seller within the meaning of section $12 . .^{43}$

42. 1933 Act $\$ 12(2), 15$ U.S.C. $\$ 77 l(2)$ (1970).

43. See Katz v. Amos Treat \& Co., 411 F.2d 1046 (2d Cir. 1969); Nicewarner v. Bleavins, 244 F. Supp. 261, 266 (D. Colo, 1965); Wonneman v. Stratford Securities Co., [1957-1961 Transfer Binder] CCH FED. SEC. L. REP. đ 91,034 (S.D.N.Y. 1961).

An attorney who undertakes more than the performance of legal services in connection with a securities transaction and actually begins to assist in the sale may be exposed to the argument that he too is a seller and may be held to answer for such further, non-legal services as he performed. See notes 101-14 infra and accompanying text.

A lawyer may also be subject to certain liabilities for statements in his or her opinion when the opinion is included in a registration statement with the lawyer's consent. Under section $11(\mathrm{a})(4)$, the liability of experts applies to:

any person whose profession gives authority to a statement made by him, who has with his consent been named as having prepared or certified any part of the registration statement ... . with respect to the statement in such registration statement ... which purports to have been prepared or certified by him. 15 U.S.C. \& $77 \mathrm{k}(\mathrm{a})(4)(1970)$.

Since Schedule A, id. $\S 77 \mathrm{aa}$, requires that a registration statement contain "a copy of the opinion or opinions of counsel in respect to the legality of the issue" and section $7, i d$. $\S$ $77 \mathrm{~g}$, is understood to require that counsel issuing the opinion consent to being named in the registration statement and to the use of the opinion letter, the lawyer may well be subject to expert status with respect to the accuracy of an opmion letter included in the registration statement. This liability as to expertised matters would, of course, be subject to the due diligence defense. See note 40 supra and accoinpanying text.

Counsel can best protect themselves from section 11 liability by careful drafting of their opinions. The opinion required of counsel under Senedule $A$ and section 7 can be carefully drawn and narrow in application. However, attorneys have not always done so 
Finally, it must be kept in inind that the due diligence provisions of sections 11 and 12 are defenses to causes of action which are explicitly authorized by the Act. These sections do not make it unlawful not to make a reasonable investigation or not to use due diligence. In fact, persons subject to the requirements of the 1933 Act could completely ignore the contents of a registration statement, and if by chance it should contain no untrue statements or omissions of required material fact, such persons would not have violated sections 11 or 12 or breached any duty under those sections. ${ }^{44}$

Under the 1933 Act, then, the lawyer performing legal services and not acting as a principal in a transaction may be subject to liability only as an expert and only as to the legal opinion which is used in the registration statement. It has been held that a lawyer is not an "expert" as to a prospectus as a result of having participated in its drafting. 45

Exemption for Municipal Bonds:

Limited Obligations of Municipal Bond Counsel

Even this limited potential for imposing liability on attorneys with respect to the registration and prospectus requirements of the Securities Act of 1933, however, is inapplicable to lawyers serving as inunicipal

and may have exposed themselves to liabilities on account of overly-broad opinions. See generally Cheek, supra note 17, at 207-211.

44. It should be emphasized that section 11 does not prohibit every omission of a material fact nor every untrue statement in a registration statement. The language is quite specific:

In case any part of the registration statement, when such part became effective,

contained an untrue statement of a material fact or omitted to state a material

fact required to be stated therein or necessary to make the statements therein

not misleading . . . . 1933 Act $\$ 11$ (a), 15 U.S.C. $\$ 77 \mathrm{k}(\mathrm{a})(1970)$.

An untrue statement will expose an individual to liability only if it concerns a material fact. And only omissions of material facts which are either required to be stated (i.e., under the provisions of Schedule A, 15 U.S.C. $\& 77$ aa (1970), or the applicable SEC regulation), or necessary to make the registration statcment not misleading are actionable. Furthermore, to be entirely accurate, section 11 does not prohibit such statements, but only provides a cause of action for one who purchases a security pursuant to a registration statement which is materially false or misleading. The prohibition of such statements is included in section 24 of the 1933 Act, 15 U.S.C. $\$ 77 x$ (1970), which provides criminal penalties for "any person who willfully, in a registration statement filed under this title, makes any untrue statement of a material fact or omits to state any material fact required to be stated therein or necessary to make statements therein not misleading . ..." It is interesting that the only prohibition of such statements in a registration statement is phrased in terms of "willful" conduct; such language certainly does not support the theory that there is an independent duty of due care on which liability can be based. 1968).

45. Escott v. BarChris Constr. Corp., 283 F. Supp. 643, 683, 689-92 (S.D.N.Y. 
bond counsel. Congress chose to grant a broad exemption from the provisions of the 1933 Act for the issue or guarantee of a security by any "political subdivision" or "political instrumentality" of a state. ${ }^{40}$ The registration statement and prospectus requirements of section 5 of the 1933 Act are generally inapplicable to the issuance of municipal securities; equally inapplicable are the section 11 and section 12 provisions pursuant to which private civil actions lie. ${ }^{47}$

Section 17 of the 1933 Act. Congress, however, expressly provided that the general anti-fraud provisions of section 17 (which contain no express civil remedy) are applicable to offers and sales of municipal securities. ${ }^{48}$ Under section 17 , individuals are prohibited from engaging in a variety of fraudulent practices in connection with an offer or sale of any security. A person ${ }^{40}$ may not use any device,

46. Section 3(a)(2), 15 U.S.C. $\$ 77 \mathrm{c}(\mathrm{a})(2)$ (1970), exempts certain classes of securities from the Act, except as otherwise expressly provided. Prominently included among the exempt securities are "any security issued or guaranteed by . . . any political subdivision of a State or territory, or by any public instrumentality of one or more states or territories ...." With the exception of certain types of industrial development bonds, see note 47 infra, this exemption covers all municipal securities.

The purpose of this exemption is indicated in the report accompanying the House version of what ultimately became the Securities Act of 1933:

[The bill] carefully exempts from its application certain types of securities and securities transactions where there is no practical need for its application or where the public benefit is too remote. H.R. REP. No. 85, 73d Cong., 1st Sess. 5 (1933).

47. The original House version of the 1933 Act did not exempt municipal securities from the provisions of section 12 . It was not until the conference committee met that the exemption of municipal securities, as included in the Senate version, was secured. Statement of the Managers on the Part of the House, H.R. REP. No. 152, 73d Cong., 1st Sess. 26-27 (Conference Report 1933).

Certain municipal securities in the nature of industrial development bonds may still not be exempt from the registration and prospectus requirements of the 1933 Act. Under SEC Rule 131, 17 C.F.R. $\$ 230.131$ (1976), municipal obligations which are payable from funds obtained in payment for property or money used in an industrial or commercial enterprise shall also be considered to be a separate security of the underlying obligor (i.e., the commercial/industrial enterprise). Unless they qualify for a tax exemption as industrial development bonds under sections $103(c)(4)$ or $(6)$ of the tax code, INT. REv. CODE of 1954, $\S 103$ (c) (4), (6), such separate securities may be non-exempt under the 1933 Act and subject to the provisions of sections 11 and 12 . See 1933 Act $\& 3(a)(2), 15$ U.S.C. $\$ 77 \mathrm{c}(\mathrm{a})(2)$ (1970).

Even if the industrial development bond can qualify for some other section 3 exemption, the underlying obligor and underwriter are unlikely to be satisfied without opinion from independent counsel. Section 12 liability may still be possible inasmuch as that section applies to all exempt securities other than those specifically exempted under section 3(a) (2) of the 1933 Act.

Because of the complexity of these tax and securities law provisions and regulations which control industrial development bonds, underwriters and the underlying obligors will frequently obtain independent counsel in such transactions.

48. 1933 Act $\S 17(c), 15$ U.S.C. $\$ 77 q(c)(1970)$.

49. "Person" includes political subdivisions. See 1933 Act $\S 2(2), 15$ U.S.C. $\S$ $77 b(2)(1970)$. 
scheme or artifice to defraud; he or she may not obtain money from a purchaser by untrue statements of a material fact or by a failure to state a material fact which is necessary to make other statements not misleading; and he or she may not engage in any transaction, practice, or course of business which would operate to defraud a purchaser. ${ }^{50}$ While authority is mixed on whether section 17 can be used to support a private action for damages, ${ }^{51}$ it seems clear that this section may be used to subject bond counsel to SEC enforcement or disbarment proceedings for improprieties in offers or sales of securities. ${ }^{52}$

Thus, with only section 17 applicable to municipal bonds, the 1933 Act imposes no explicit duties on bond counsel. Nor are any extensive duties to be inferred by analogy to provisions for registered securities.

The 1934 Act. No more explicit guide to the duties of bond counsel is provided by the Securities Exchange Act of 1934. Municipal bonds are generally exempt from the requirements of the 1934 Act, ${ }^{53}$ but, as with 1933 Act, the 1934 Act's anti-fraud provisions, concontained in section $10(\mathrm{~b})$ and its companion, rule $10 \mathrm{~b}-5$, are applicable to all securities including municipal bonds. ${ }^{54}$ Rule $10 \mathrm{~b}-5$ is similar

50. 1933 Act $\$ 17$ (a), 15 U.S.C. $\$ 77 q(a)$ (1970). Section $17(b), 15$ U.S.C. $\$$ $77 q(b)$ (1970), the "anti-tipster sheet" provision, also applies to sales of municipal securities. This provision prohibits touting a security for a fee without disclosing that the publisher has been paid to do so. This section has not been the source of much reported litigation and, in any case, has little relevance to any problem bond counsel might be expected to face. See H.R. REP. No. 85, 73d Cong., 1st Sess. 24 (1933).

51. See note 55 infra and cases cited therein.

52. See 1933 Act $\S 20,15$ U.S.C. $\$ 77 \mathrm{t}$ (1970); SEC Rules of Practice 201.2, 17 C.F.R. $\S 201.2(1976)$.

53. See 1934 Act $\$ 3(a)(12), 15$ U.S.C. $\$ 78 c$ (a) (12) (1970).

54. 1934 Act $\S 10(b), 15$ U.S.C. $\$ 78 j(b)$ (1970); Securities Exchange Act Rule 10b-5, 17 C.F.R. $\$ 240.10$ b-5 (1976). The 1934 Act's definition of "person" was specifically anrended to include political subdivisions in 1975. Securities Reform Act of 1975 \$ 3(2), 15 U.S.C.A. \& 78(c) (9) (Supp. 1976).

At least in theory, the Securities Exchange Act and all its provisions should have little application to bond counsel. The 1934 Act was really not intended to regulate the issuance of securities. Rather, the Act was intended primarily to regulate secondary trading in issued securities, exchanges, brokers and dealers. Because bond counsel performs services in connection with the issuance of the municipal security, and not its subsequent trading, the 1934 Act should not, in theory, be a significant repository of duties with respect to him. Yet courts rarely, if ever, seem to consider the linited purpose of the 1934 Act as liniting the provisions of section 10 (and rule 10b-5 adopted thereunder).

Recently, however, in Ernst \& Ernst v. Hochfelder, 425 U.S. 185 (1976), the Supreme Court expressly recognized the intended relation between the two securities acts:

The Securities Act of $1933 \ldots$ was designed to provide investors with full disclosure of material information concerning public offerings of securities in commerce, to protect investors against fraud and, through the imposition of 
to section 17 of the 1933 Act in prohibiting fraudulent practices. ${ }^{55}$ Rule 10b-5 applies more broadly, however, not simply to any offer or sale but "in connection with the purchase or sale of any security." Simce section $10(\mathrm{~b})$ and rule $10 \mathrm{~b}-5$ have been held to give rise to a private

specified civil liabilities, to promote ethical standards of honesty and fair dealing. See H.R. REP. No. 85, 73d Cong., 1st Sess. 1-5 (1933). The 1934 Act was intended principally to protect investors against manipulation of stock prices through regulation of transactions upon securities exchanges and in overthe-counter markets, and to impose regular reporting requirements on companies whose stock is listed on national securities exchanges. See S. REP. No. 792, 73d Cong., 2d Sess. 1-5 (1934). 425 U.S. at 195 (emphasis added, citation omitted).

Given the distinctly different purposes behind the statutes, and the provision of express civil remedies in only the 1933 Act to cover public issuance of securities, there is a strong argument against allowing rule $10 \mathrm{~b}-5$ to be used to imply additional civil remedies for conduct occurring in securities issues regulated by the 1933 Act. In Blue Chip Stamps v. Manor Drug Stores, 421 U.S. 723 (1975), the Supreme Court, on its own initiative, expressly recognized the existence of the argument that the 1933 Act's remedies may be exclusive, but declined to rule on it. Id. at 733-34 n.6.

Even if the exclusivity of 1933 Act civil remedies is ultimately accepted, its applicability to municipal security transactions would be in doubt because such securities are not regulated by the $1933 \mathrm{Act}$, and hence no express remedies exist with respect to such securities.

55. The similarity between section 17 of the 1933 Act and rule 10b-5 is, at first reading, striking. Section 17 provides:

(a) It shall be unlawful for any person in the offer or sale of any securities by the use of any means or instruments of transportation or communication in interstate commerce or by the use of the mails, directly or indirectly-

(1) to employ any device, scheme or artifice to defraud, or

(2) to obtain money or property by means of any untrue statement of a material fact or any omission to state a material fact necessary in order to make the statements made, in the light of the circumstances under which they were made, not misleading, or

(3) to engage in any transaction, practice, or course of business which operates or would operate as a fraud or deceit upon the purchaser.

Rule 10b-5 reads as follows:

It shall be unlawful for any person, directly or indirectly, by the use of any means or instrumentality of interstate commerce, or of the mails or of any facility of any national securities exchange,

(1) to employ any device, scheme, or artifice to defraud,

(2) to make any untrue statement of a material fact or to omit to state a material fact necessary in order to make the statements made, in the light of the circumstances under which they were made, not misleading, or

(3) to engage in any act, practice, or course of business which operates or would operate as a fraud or deceit upon any person, in connection with the purchase or sale of any security.

So great is the similarity that some courts have erroneously concluded that there is an identity between the two for purposes of testing the existence and scope of an implied private remedy. See, e.g., MacAndrews \& Forbes Co. v. American Barmag Corp., 339 F. Supp. 1401 (D.S.C. 1972); Thiele v. Shields, 131 F. Supp. 416 (S.D.N.Y. 1955). This view is incorrect. Legislative history amply demonstrates that Congress did not intend that a private remedy would lie for violation of section 17; Congress expected, rather, that the civil liabilities created by sections 11 and 12 of the 1933 Act would be sufficient to make the 1933 Act enforceable. See, e.g., H.R. REP. No. 85, 73d Cong., 1st Sess. 9 (1933). No such clear legislative limitation exists as to section 10 of the 1934 Act or rule 10b-5. See, e.g., S. REP. No. 792, 73d Cong., 1st Sess. 5-6 (1934). Nevertheless, 
cause of action for damages ${ }^{56}$ and since they have been held to apply to the various participants in connection with securities transactions, ${ }^{57}$ this section and rule becoine a primary source of possible imposition of securities law duties on bond counsel.

As will be shown, however, the text of section $10(\mathrm{~b})$ and rule 10b-5 are directed simply at prohibiting fraud or misleading representations. They impose no requirement of reasonable investigation such as is required to establish the due diligence defense.

The Securities Reform Act of 1975 and the Tower Amendment. The Securities Reforn Act of 1975 confirmed Congress' intent not to impose federal regulation on issuers of state or local government securities. The Reforn Act annended the Securities Exchange Act of 1934 to require federal registration of municipal securities dealers and brokers ${ }^{58}$ both of whom had previously been exempted froin registration. To administer the new provisions, a Municipal Securities Rulemaking Board was also established with powers to regulate mumcipal brokers and dealers. ${ }^{59}$

current authority is divided on the issue of whether a private right of action for damages can be implied under section 17. See Dorfman v. First Boston Corp., 336 F. Supp. 1089, 1093-95 (E.D. Pa. 1972). Courts have held both ways. Compare Reid v. Mann, 381 F. Supp. 525 (N.D. Ill. 1974); Dyer v. Eastern Trust \& Banking Co., 336 F. Supp. 890 (D. Me. 1971) (no private right of action under section 17(a)), and Trussell v. United Underwriters, Ltd., 228 F. Supp. 757 (D. Colo. 1964) (no right of action under section 17(a) unless provided by sections 11 or 12), with MacAndrews \& Forbes Co. v. American Barmag Corp., 339 F. Supp. 1401 (D.S.C. 1972) (implies private cause of action under both section 17(a) and section 10(b)); Dorfman v. First Boston Corp., 336 F. Supp. 1089 (E.D. Pa. 1972), and Dack v. Shanman, 227 F. Supp. 26 (S.D.N.Y. 1964) (implies right of action under section 17(a)). Thus far the Supreme Court has avoided settling the issue. See, e.g., Blue Chip Stamps v. Manor Drug Stores, 421 U.S. 723, 733-34 n.6 (1975).

The two sections also contain an important difference in wording. Section 17 applies to the "offer or sale" of a security. Although an actual sale is not necessary, only actions by the seller are prohibited. Rule $10 \mathrm{~b}-5$, on the contrary, prohibits similar behavior, but "in connection with the purchase or sale" of a security. Thus, while both buyer and seller are within the scope of rule $10 \mathrm{~b}-5$, there must be an actual purchase or sale in order to have the rule apply. Blue Chip Stamps v. Manor Drug Stores, 421 U.S. 723 (1975). In short, rule 10b-5 needs a transaction, section 17 does not; rule 10b-5 applies to buyer and seller, section 17 to seller alone.

56. Blue Chip Stamps v. Manor Drug Stores, 421 U.S. 723 (1975).

57. See Superintendent of Ins. v. Bankers Life \& Cas. Co., 404 U.S. 6, 9-12 (1971). See also Ernst \& Ernst v. Hochfelder, 425 U.S. 185 (1976) (accountants); Sanders v. John Nuveen \& Co., 524 F.2d 1064 (7th Cir. 1975), vacated and remanded, 425 U.S. 929 (1976) (underwriters); SEC v. Spectrum, Ltd., 489 F.2d 535 (2d Cir. 1973) (lawyer giving an opinion); SEC v. Texas Gulf Sulphur Co., 401 F.2d 833 (2d Cir. 1968), cert. denied, 394 U.S. 976 (1969) (issuers, controlling officers and shareholders).

58. Securities Reform Act of 1975 \& 15B(a) (1), 15 U.S.C.A. $\$ 780-4$ (a) (1) (Supp. 1976). For a detailed discussion of the effect of these amendments on participants in municipal securities issues, see Comment, supra note 3, at 1270-74.

59. Securities Reform Act of $1975 \S 15 B(b), 15$ U.S.C.A. $\$ 780-4$ (b) (Supp. 1976). 
The 1975 legislation was specifically amended on the floor of the Senate, however, to prohibit both the SEC and the Rulemaking Board from requiring any issuer of municipal securities, either directly or indirectly through a purchaser, to file any application, report or document with the SEC or the Board prior to a sale of securities. ${ }^{60}$ Under the second provision of this so-called Tower Amendnent, the Municipal Securities Rulemaking Board is without power to require issuers to provide any information at any tine to the Board or to purchasers. ${ }^{61}$ The SEC, however, has implicit authority to request information from an issuer after its issue is completed. ${ }^{62}$ The Board may also require brokers or dealers, at any time, to file or provide purchasers with documents or information which are available from a source other than the issuer. ${ }^{63}$ While the Board is empowered to promulgate rules regulating a variety of broker-dealer activities, ${ }^{84}$ neither it nor the SEC has established any disclosure requirements for municipal securities official statements.

Thus, the Tower Amendment has not led to substantial changes in the law applicable to municipal issuers or bond counsel. Section 17(a) of the 1933 Act and section 10(b) of the 1934 Act still apply to municipal bond sales. While neither the SEC nor the Board may require a municipality to provide any infornation about its securities prior to their sale, participants in municipal issues remain prohibited from making false or misleading representations, or from omitting information needed to make representations not misleading. At most, the SEC's asserted power to request information from municipal issuers after their sale niay facilitate prosecution of anti-fraud proceedings. ${ }^{65}$

\section{SEC Enforcement Powers}

One final aspect of federal regulation which deserves special men-

The composition and powers of the Board are discussed in Comment, supra note 3, at 1272. See also Note, Disclosure by Issuers of Municipal Securities: An Analysis of Recent Proposals, 29 VAND. L. Rev. 1017, 1018-19 (1976). 1976).

60. Securities Reform Act of $1975 \S 13 B(d)(1), 15$ U.S.C.A. $\S 780-4$ (d)(1) (Supp. 1976).

61. Securities Reform Act of $1975 \S 13 B(d)(2), 15$ U.S.C.A. $\$ 780-4(d)(2)$ (Supp.

62. See id.

63. Id.

64. These permissible areas of regulation are discussed in Comment, supra note 3, at 1272 .

65. There are a variety of proposals presently before Congress which would increase the powers of the Commission and/or Rulemaking Board, change the applicability of the 1933 Act to municipal securities, and/or legislate special disclosure provisions for municipals. These proposals are discussed in Comment, supra note 3, at 1274-88. See note 3 supra for cases contesting the SEC's investigatory power as to political subdivisions. 
tion is the broad discretionary investigative and enforcement powers of the SEC. Under both the 1933 and 1934 Acts, the SEC may begin investigations whenever it believes that the securities laws or regulations have been or are about to be violated. ${ }^{b 8}$ The SEC has further discretion to seek to enjoin persons believed to be violating or about to violate the securities laws. ${ }^{67}$ The substantial enforcement power of the SEC, and the apparent willingness of many courts to require less than exacting standards in such enforceinent proceedings, ${ }^{68}$ is a source of major concern to participants in security transactions. This concern is particularly acute for lawyers since the mere initiation of such an action may be very damaging to professional reputation. Moreover, under SEC rules of practice, a lawyer may be suspended from practice before the Commission when the SEC finds that he or she has violated or has willfully aided or abetted a violation of the securities laws or regulations. ${ }^{69}$ Bond counsel are subject to SEC scrutiny under the anti-fraud provisions of section 17 , section 10 and rule $10 \mathrm{~b}-5 .^{70}$

The focus, then, for consideration of the application to bond counsel of either possible civil liability or of the enforcement powers of the SEC must be on the anti-fraud provisions of the statutes. The judicial and administrative interpretation given these provisions requires careful review, and it is to this problem that we now turn our attention.

\section{Section 17 and Rule 10b-5 as Applied to Lawyers}

Understanding section 17 of the 1933 Act and section 10(b) and rule 10b-5 of the 1934 Act has proven extremely difficult. Each was adopted as a broad prohibition of deceptive practices not otherwise expressly prohibited. ${ }^{71}$ The language of each is therefore broad. ${ }^{72}$

66. 1933 Act $\$ 20,15$ U.S.C. $\$ 77 \mathrm{t}(1970) ; 1934$ Act $\$ 2 \mathrm{I}, 15$ U.S.C. $\$ 78 \mathrm{u}$ (I970).

67. 1933 Act $\$ 20,15$ U.S.C. $\$ 77 t$ (1970); 1934 Act $\$ 21,15$ U.S.C. $\$ 78 u$ (1970).

68. See, e.g., SEC v. National Student Marketing Corp., 402 F. Supp. 641 (D.D.C. 1975) (reckless disregard); SEC v. Spectrum, Ltd., 489 F.2d 535 (2d Cir. 1973) (negligence). Ernst \& Ernst v. Hochfelder, 425 U.S. 185 (1976), which involved a private action, did not resolve the question of the standard of liability to be applied in an SEC enforcement action. Id. at 193-94 n.12. See notes 97-99 infra and accompanying text.

69. 17 C.F.R. $\& 201.2(\mathrm{e})$ (1976). Apparently, the SEC would apply standards in its own disbarment proceedings that are different from those it has urged in injunctive proceedings: an attorney may only be disbarred or suspended for aiding and abetting when his or her conduct is "willful," $i d$., while the SEC has urged a negligence standard in injunction proceedings. See, e.g., SEC v. Spectrum, Ltd., 489 F.2d 535, 541 (2d Cir. 1973), discussed in text accompanying notes 102-05 infra.

70. See SEC v. Ferguson, Securities Act of 1933 Release No. 5523 (Aug. 21, 1974).

71. Consider, for example, the explanations of the purpose behind section 10 of the 1934 Act offered in S. Rep. No. 792, 73d Cong., 2d Sess. 7-9 (1934), and 78 CoNG. REC. 2271 (1934) (remarks of Sen. Fletcher). The drafters referred to section 
Each provision has generated enormous differences over its meaning. While prohibiting misrepresentations, these provisions do not explicitly prescribe any standard of culpability. Such a standard, of course, is crucial to the question of the exposure of bond counsel.

\section{The Standard of Liability: Ernst \& Ernst v. Hochfelder}

Until recently, there had been nearly total disagreement anong the circuits concerning the standard of liability to be applied in actions brought under rule $10 \mathrm{~b}-5$. The standard liad ranged from "intentional" conduct to "negligent" conduct and had included a "flexible" standard to be applied on a case-by-case basis. ${ }^{73}$ The Supreme Court chose to end the nearly two decades of debate on the requisite degree of fault under rule 10b-5 in Ernst \& Ernst v. Hochfelder. ${ }^{74}$ The Sev-

10 as a "catch-all" which would allow the SEC "to deal with new manipulative [or cunning] devices." Ernst \& Ernst v. Hochfelder, 425 U.S. 185, 203 (1976).

72. The provisions of section 17 and rule 10b-5 are set forth in note 55 supra.

73. The standard varied widely and fluctuated. See Ernst \& Ernst v. Hochfelder, 425 U.S. 185, 193-94 n.12, 197 n.17 (1976). For example, the Second Circuit Court of Appeals had seemingly rejected the possibility that a purely unintentional action might violate rule $10 \mathrm{~b}-5$, and instead required the demonstration of some form of scienter. Lanza v. Drexel \& Co., 479 F.2d 1277, 1306 (2d Cir. 1973); SEC v. Texas Gulf Sulphur Co., 401 F.2d 833 (2d Cir. 1968), cert. denied, 394 U.S. 976 (1969). In the Seventh Circuit the law had evolved to the point where negligent omission to act was sufficient to constitute a violation of the rule. Hochfelder v. Midwest Stock Exchange, 503 F.2d 364 (7th Cir.), cert. denied, 419 U.S. 875 (1974); Hochfelder v. Ernst \& Ernst, 503 F.2d 1100 (7th Cir. 1974), rev'd, 425 U.S. 185 (1976). On the other hand, the Tenth Circuit finally concluded, in Clegg v. Conk, 507 F.2d 1351, 1361-62 (10th Cir. 1974), cert. denied, 422 U.S. 1007 (1975), after futilely attempting to reconcile irreconcilable earlier rulings, that some form of "conscious fault" was required. The Ninth Circuit, seemingly weary of the fray, capitulated in White v. Abrams, 495 F.2d 724, 730 (9th Cir. 1974), and ruled that there was no fixed standard, but rather a flexible standard which would depend upon the facts of each case. For the most part, commentators were, if anything, less illuminating than the courts in discussing the scienter question, with the exception of Bucklo, Scienter and Rule 10b-5, 67 Nw. U.L. REv. 562 (1972), which exposed the divergence between courts' purported application of a negligence standard and the actual scienter each court was finding. In January of 1974, SEC Commissioner A.A. Sommer, Jr. alarmed many practitioners with a speech which predicted far-reaching due diligence responsibilities for the attorney on the basis of interpretations of the anti-fraud provisions. See Sommer, supra note 6.

74. 425 U.S. 185 (1976). Other aspects of rule 10b-5 had been considered by the Court starting in 1971. Superimtendent of Ins. v. Bankers Life \& Cas. Co., 404 U.S. 6 (1971) (the "in connection with" requirement); Affiliated Ute Citizens v. United States, 406 U.S. 128 (1972) (the "reliance" element); Blue Chip Stamps v. Manor Drug Store, 421 U.S. 723 (1975) (the "purchase or sale" requirement). Prior to these decisions, no Supreme Court decision had specifically addressed the elements of the implied private cause of action despite its recognition by the lower courts since 1946, see Kardon v. National Gypsuin Co., 69 F. Supp. 512 (E.D. Pa. 1946), and the tremendous case law, comment and controversy it had generated. 
enth Circuit had ruled that a claim for relief had been stated under rule $10 b-5$ against an accounting firm where it was alleged that but for a negligently performed audit, the accountants would have discovered evidence leading to exposure of a fraud being consciously perpetrated by the president of a brokerage liouse on his customers. ${ }^{75}$ Plaintiffs had never claimed that Ernst \& Ernst actually knew of the fraud or knowingly acted to facilitate it. The Supreine Court reversed the Seventh Circuit, holding that no private action for money damages would lie in the absence of an allegation of scienter ${ }^{76}$ _"a mental state embracing intent to deceive, inanipulate or defraud."77 The Hochfelder Court also interpreted "manipulation" very narrowly as connoting "intentional or willful conduct designed to deceive or defraud investors by controlling or artificially affecting the price of securities." $" 78$

The innportance of this decision cannot be overemphasized. Hochfelder firmly rejects an expansive view of rule 10b-5. Significantly, in reaching its decision, the Court started with and rehied heavily upon the actual wording of both the section and the rule. ${ }^{79}$ Equally important, the Court buttressed its decision by construing the 1933 and 1934 Acts together and by resort to available legislative history, both of which strongly weighed against a negligence standard..$^{80}$

In Hochfelder, the Court explicitly declined to consider and decide three important issues related to the scienter requirement. First, the Court noted that its disposition of the case made it unnecessary "to consider whether civil liability for aiding and abetting is appropriate under the section and the rule." 81 Second, the Court declined to decide whether "in some circuinstances, reckless behavior is sufficient for civil liability under $\S 10(\mathrm{~b})$ and Rule 10b-5."82 Finally, the Court reserved the issue of "whether scienter is a necessary element in an action for injunctive relief under $\S 10(b)$ and Rule $10 b-5 . " 83$

The concept of aiding and abetting, a curious form of secondary liability, is derived from judicial construction of rule $10 \mathrm{~b}-5$. Neither the language nor the legislative history of either securities act describes

75. Hochfelder v. Ernst \& Ernst, 503 F.2d 1100 (7th Cir. 1974), rev'd, 425 U.S. 185 (1976).

76. 425 U.S. at 193.

77. Id. at 194 n. 12 .

78. Id. at 199.

79. See id. at $197-201,212-14$.

80. See id. at 195-201. See also id. at 212-14 (administrative history of the rule).

81. Id. at 192 n.7.

82. Id. at 194 n.12.

83. Id. 
"aiding and abetting" as giving rise to a private action. ${ }^{84}$ The concept apparently found its way into rule $10 \mathrm{~b}-5$ civil actions from the Restatement of Torts in the district court's decision in Brennan v. Midwestern Life Insurance. ${ }^{85}$ Such an action requires a showing that a party violated the securities laws, and that the aider and abettor had knowledge of that violation and knowingly and substantially assisted in its perpetration. ${ }^{80}$ The aiding and abetting concept appears to be intended to inculpate individuals on the periphery of a securities transaction, making them share responsibility for conduct of the principals. ${ }^{87}$ Thus lawyers, accountants, lending institutions and the like have all been charged with aiding and abetting violations of rule $10 \mathrm{~b}-5 .^{\mathbf{8 8}}$

84. There is no mention of aiding and abetting anywhere in section 17 of the 1933 Act or the 1934 Act's section 10 or rule 10b-5. See generally Ruder, Multiple Defendants in Securities Law Fraud Cases: Aiding and Abetting, Conspiracy, In Pari Delicto, Indemnification and Contribution, 120 U. PA. L. REv. 597 (1972). Where Congress wanted to forbid aiding and abetting security law violations, it did so explicitly. See, e.g., 1934 Act \& 15(b)(4)(E), 15 U.S.C.A. \& 77l(b)(4)(E) (Supp. 1976). The concept presently appears only in SEC Rules of Practice, 17 C.F.R. \& 201.2(e)(1)(iii) (1976), governing suspension and disbarment of SEC practitioners. While aiding and abetting clauses now seem commonplace in cases charging violations of rule 10b-5 or section 17 , there is judicial authority to the effect that aiding and abetting does not give rise to a claim under sections 11 or 12 of the 1933 Act on the ground that to do so would circumvent the express congressional provision of remedies. In re Equity Funding Corp. of Am. Sec. Litigation, 416 F. Supp. 161, 181 (C.D. Cal. 1976). By contrast, the aiding and abetting theory has been employed to enjoin an attorney from violating section 5(a) of the 1933 Act. SEC v. Universal Major Indus. Corp., [1975-1976 Transfer Binder] CCH FED. SEC. L. REP. If 95,229 (S.D.N.Y. 1975). Finally, there is some authority for the proposition that the controlling persons liability as set forth in section 20 of the 1934 Act may be the exclusive vehicle for imposing secondary liability. See Gordon v. Burr, 366 F. Supp. 156, 168 (S.D.N.Y. 1973), aff'd, 506 F.2d 1080 (2d Cir. 1974).

85. 286 F. Supp. 702 (N.D. Ind. 1968), aff'd, 417 F.2d 147 (7th Cir. 1969), cert. denied, 397 U.S. 989 (1970). The concept, as applied by the district court and accepted by the court of appeals, was apparently borrowed from the RESTATEMENT OF TORTS $\$$ 876 (1939). See Ruder, supra note 84 , at 620 . The concept also has a criminal law counterpart. See 18 U.S.C. $\$ 2$ (a) (1970) (making an aider and abettor punishable as a principal under federal criminal law).

86. Woodward v. Metro Bank, 522 F.2d 84, 97 (5th Cir. 1975). Woodward contains the best discussion of aiding and abetting to be found in a judicial opinion.

87. See 2 A. Bromberg, Securities LAW: Fraud $\$ 8.5(530)$ (1975).

88. See Keene Corp. v. Weber, 394 F. Supp. 787 (S.D.N.Y. 1971) (claims of aiding and abetting against lawyer dismissed with comment by court):

This case is indicative of an unfortunate tendency, which has become all too prevalent, to proceed on speculative assumptions, in the absence of a sound factual foundation, against professional men as aiders and abettors, for the supposed in terrorem effect thereof due to the potentially coercive impact of such a suit on their professional status and reputation. Id. at 789.

Additionally, see Ernst \& Ernst v. Hochfelder, 425 U.S. 185 (1976) (accountants); Woodward v. Metro Bank, 522 F.2d 84 (5th Cir. 1975); Wessel v. Buhler, 437 F.2d 279 (9th Cir. 1971) (accountants); Fischer v. New York Stock Exchange, 408 F. Supp. 745 (S.D.N.Y. 1976) (stock exchange); Saltzman v. Zern, 407 F. Supp. 49 (E.D. Pa. 1976) 
There has been disagreement among the lower courts concerning the application of theories of aiding and abetting in both civil actions and SEC injunction proceedings. ${ }^{89}$ Hochfelder, however, should abate this controversy. If, as Hochfelder held, money damages lie only for willful violations of the rule, it would hardly seem that one whose liability is premised on aiding and abetting could be held liable for damages under a less stringent scienter standard. Liability for an aiding and abetting violation should only exist, if at all, where the alleged aider and abettor had actual knowledge of a violation and knowingly provided substantial assistance in its perpetration. The curiousness of requiring aiding and abetting allegations to meet this standard lies in the fact that any such conduct will in and of itself directly violate rule $10 \mathrm{~b}-5$. It is difficult to hypothesize a situation where all three elements are satisfied without simultaneously hypothesizing an independent violation of one of the anti-fraud provisions of the rule. Indeed, it is possible that the Court's specific refusal to consider aiding and abetting as a cause of action reflects its belief that the aiding and abetting theory is misplaced in rule $10 \mathrm{~b}-5$ or section 17 securities hitigation.

Of particular interest to bond counsel is the possible application of a "reckless" or "wanton" standard to allegations that an attorney aided and abetted a securities violation by performing legal services. ${ }^{90}$ Whenever an attorney's services are deemed necessary for the completion of a securities transaction, performance of those services may satisfy the substantial assistance element for aiding and abetting if a securities violation occurs in connection with the transaction. In such an

(bank); U.S. Steel v. Orenstein, [1976-1977 Transfer Binder] CCH SEC. L. REP. II 95,680 (S.D.N.Y. 1976); H.L. Federman \& Co. v. Greenberg, 405 F. Supp. 1332 (S.D.N.Y. 1975) (supplier lending money to direct violator).

89. Compare SEC v. Coffey, 493 F.2d 1304, 1316 (6th Cir. 1974) cert. denied, 420 U.S. 908 (1975) (requiring that an aider and abettor have "general awareness that his role was part of an overall activity that was improper"), with Woodward v. Metro Bank, 522 F.2d 84, 97 (5th Cir. 1975) (requiring actual knowledge of the violation and knowing and substantial assistance in its perpetration).

The criteria for aiding and abetting liability in the context of a civil danage action may differ from those applied in an SEC enforcement proceeding. See notes 97-98 infra and accompanying text. See, e.g., SEC v. World Radio Mission, Inc. [1976-1977 Transfer Binder] CCH FED. SEC. L. REP. If 95,751 (1st Cir. 1976) (intent held irrelevant in an SEC injunctive proceeding); Woodward v. Metro Bank, 522 F.2d 84, 97 (5th Cir. 1975); SEC v. Bausch \& Lomb, Inc., [1976-1977 Transfer Binder] CCH Fed. SEc. L. Rep. Tी 95,722 (S.D.N.Y. 1976) (scienter required).

90. However, because the concept of "reckless" or "wanton" manipulation or contrivance is as bizarre as "negligent" manipulation or contrivance, cf. Hochfelder, 425 U.S. at 214 , consistency with the decision suggests that the Court should reject any allegation short of intentional violation as constituting a cause of action under rule $10 \mathrm{~b}-5$. 
event, the only significant issue left to be resolved would be the state of mind of the attorney. Use of a "wanton" or "reckless" standard might expose the attorney to liability for performing legal services even though he or she knew nothing of the fraud. Under such an aiding and abetting standard, a lawyer could incur liability for conduct which is legal in and of itself-the issuance of a truthful opinion letter, for example-if done in connection with a fraudulent securities transaction, even though the attorney was in fact unaware of the fraud. By refusing to decide whether allegations of reckless or wanton conduct are sufficient to state a cause of action under rule 10b-5, the Supreme Court failed to eliminate judicial second-guessing of participants in security offerings. As long as liability for money daunages may be predicated on conduct that is short of intentional, the courts will be forced to continue to permit juries to engage in "should have been" or "could have been" reasoning.

Even this approach to aiding and abetting, however, would not appear to impose general duties of investigation upon the attorney. Rather, the attorney would be exposed to liability only after recklessly or wantonly disregarding indications of fraud which arose in connection with the performance of legal services and continuing to assist in the fraudulent transaction. There is no indication that a duty to investigate the total securities transaction to determine its soundness would be imposed. Indeed, such a rule would directly conflict with the 1933 Act's careful limitations on liability. ${ }^{01}$

The question of what constitutes reckless conduct has not yet been settled. One possible approach might employ an analogy from the libel decisions, an area of the law which is also concerned with the dissemination of false or misleading information. Under the current case law, a person is held to have acted with "reckless" disregard for the truth if he publishes defamatory matter under circumstances indicating its probable falsity. ${ }^{02}$ According to the Supreme Court, this standard of reckless conduct

is not measured by whether a reasonably prudent man would have published, or would have investigated before publishing. There must be sufficient evidence to permit the conclusion that the defendant in fact entertained serious doubts as to the truth of his publication. ${ }^{\text {13 }}$

Recklessness is not to be inferred unless the allegations at issue "are so inherently improbable that only a reckless man would put thein into

91. See notes $29-45$ supra and accompanying text.

92. See Garrison v. Louisiana, 379 U.S. 64, 74 (1964).

93. St. Amant v. Thoinpson, 390 U.S. 727, 731 (1968). 
circulation."94 There ought to be "obvious reasons to doubt the veracity of the informant or the accuracy of his reports." Similarly, in the securities law context, an individual should not be held liable for reckless conduct unless he discloses information which is "so inherently improbable that only a reckless man would put [it] in circulation."96 Unless a purchaser can point to obvious reasons for an individual to have entertained serious doubts about the accuracy of information disclosed in connection with a securities sale, that individual should not be held responsible under rule $10 \mathrm{~b}-5$.

Finally, regardless of the outcome of the preceding two issues in connection with civil remedies implied under rule $10 \mathrm{~b}-5$, the Supreme Court has yet to establish a standard of fault for SEC enforceinent proceedings. There is an impressive line of authority which holds that a party may be enjoined on account of neghigent violations of rule $10 \mathrm{~b}-5$ or section 17.97 Since the Hochfelder decision, at least three federal courts have differed over the standard of fault to be applied in an injunctive proceeding by the SEC. ${ }^{98}$ While the inaintenance of separate and distinct requirements for actions for inoney damages and injunctive proceedings would be inore of an exercise in legerdemnain than logic, participants in securities transactions must recognize that this anomalous situation is presently possible. The specific relevance of the conflicting pre-Hochfelder case law for the question of lawyers' hability is discussed in detail below.99

While its holding that an action for money damages will not lie under rule $10 \mathrm{~b}-5$ in the absence of an allegation of an intentional violation is extremely important, Hochfelder does not appear to have any direct effect on previous decisions concerning the duties of lawyers un-

94. Id. at 732.

95. Id.

96. A similar analogy is appropriate to the recklessness standard in the aiding and abetting context. An individual should not be held liable for reckless aiding and abetting unless he acts in the face of a situation which is so likely to involve fraud that only a reckless person would have facilitated its perpetration.

97. See, e.g., SEC v. Spectrum, Ltd., 489 F. $2 d 535$ (2d Cir. 1973); SEC v. Frank, 388 F.2d 486 (2d Cir. 1968); SEC v. National Student Marketing Corp., 402 F. Supp. 641 (D.D.C. 1975); SEC v. Rega, [1975-1976 Transfer Binder] CCH FED. SEC. L. REP. II 95,222 (S.D.N.Y. 1975); SEC v. Century Investınent Transfer Corp., [1971-1972 Transfer Binder] CCH FED. SEC. L. REP. II 93,232 (S.D.N.Y. 1971).

98. Compare SEC v. Bausch \& Lomb, Inc., [1976-1977 Transfer Binder] CCH FED. SEC. L. REP. II 95,722 (S.D.N.Y. 1976) (scienter required), with SEC v. World Radio Mission, Inc., [1976-1977 Transfer Binder] CCH FED. SEc. L. REP. If 95,751 (1st Cir. 1976) (intent held irrelevant in an SEC imjunction action), and SEC v. Geotek, [19761977 Transfer Binder] CCH FED. SEC. L. REP. If 95,756 (N.D. Cal. 1976) (negligence standard applied).

99. See notes 102-19 infra and accompanying text. 
der the anti-fraud sections of the securities laws. There have been few reported cases in which an attorney was named as defendant to a private action for damages brought solely under rule $10 \mathrm{~b}-5$ or section $17 ;^{100}$ there does not appear to be any reported decision in which an attorney was ultimately held liable for money damages in a private action under rule $10 \mathrm{~b}-5$ or section 17 . Thus, despite all the pre-Hochfelder dicta and professional commentary on the expanding duties of the attorney under the anti-fraud provisions, the 1nuch-heralded expansion never achieved formal judicial sanction. In fact, the Hochfelder decision may be construed as an implicit affirmation by the Supreme Court of those decisions which refused to hold the lawyer answerable in a private action brought under the anti-fraud provisions.

\section{The Standard for SEC Enforcement Proceedings}

The attorney's liability in connection with the issuance of securities has been developed more thoroughly in the context of SEC enforcement proceedings. ${ }^{101}$ Because the Hochfelder Court did not establish a standard of liability for section 17 mjunction proceedings, this body of law retains precedential value. The leading case discussing the attorney's liability im this context is SEC v. Spectrum, Ltd., ${ }^{102}$ in which the Second Circuit held that an attorney may be enjoined for negligent violation of section 17 and rule 10b-5. According to the court, "the public trust demands more of its legal advisers than 'customary' activities which prove to be careless." 103 In order to enforce this standard against securities counsel, the Second Circuit suggested that the SEC can seek to enjoin an attorney for the misleading use of an opinion letter unless the lawyer can establish that he or she exercised due care in providing the letter. Although the court's imposition of a negligence standard on the attorney may seem threatening to the bar, it should be emphasized that the duty imposed is narrowly drawn:

100. See Katz v. Amos Treat \& Co., 411 F.2d 1046 (2d Cir. 1969); Keene Corp. v. Weber, 394 F. Supp. 787 (S.D.N.Y. 1975); Black \& Co. v. Nova-Tech, Inc., 333 F. Supp. 468 (D. Ore. 1971); Lanza v. Drexel \& Co., 271 F. Supp. 684 (S.D.N.Y. 1970), aff'd, 479 F.2d 1277 (2d Cir. 1973); Nicewarner v. Bleavins, 244 F. Supp. 261 (D. Colo. 1965). No civil action under rule $10 \mathrm{~b}-5$ has been found which has proceeded to judgment against attorneys who did no more than perform legal services.

101. See cases cited note 98 supra. See also United States v. Benjamin, 328 F.2d 854

(2d Cir. 1964); United States v. Crosby, 294 F.2d 928 (2d Cir. 1961).

102. 489 F.2d 535 (2d Cir. 1973).

103. Id. at 542 .

The legal profession plays a unique and pivotal role in the effective implennentation of the securities laws. Questions of compliance with the intricate provisions of these statutes are ever present and the smooth functioning of the securities markets will be seriously disturbed if the public cannot rely on the expertise proffered by an attorney when he renders an opinion . . . I Id. 
The standard of culpability [the court finds] appropriate for the author of an opinion letter in an action for injunctive relief only should not be construed to apply to more peripheral participants in an illicit scheme or, for that matter, to criminal prosecutions or private suits for damages. ${ }^{104}$

Thus, Spectrum is limited to the attorney's responsibility for the accuracy of a legal opinion letter in the context of its issuance. ${ }^{105}$ The case does not impose due diligence duties on an attorney with respect to any other aspect of the securities transaction.

Other reported attorney injunction cases under rule $10 \mathrm{~b}-5$ and section 17 have similarly restricted holdings. For example, in SEC $v$. National Student Marketing Corp. ${ }^{106}$ the district court, in rejecting cross-motions for summary judgment, expressed willingness to enjoin an attorney if he "actually knew that a fraudulent scheme was envisioned by NSMC, or else recklessly ignored what should have been readily apparent."107 The court declined to consider whether mere negligence would have been sufficient, since there was ample evidence that the attorney had acted either recklessly or with knowledge. The attorney in that case had supplied two opinion letters establishing the effective date for the sale of a business enterprise. While the form of the transaction may techmically have constituted an effective sale on the date so given, the transaction in substance was a sham. Since the attor-

104. Id.

105. Intimately connected with the section 17 or rule $10 \mathrm{~b}-5$ injunction is the issue of the propriety of injunctive relief. In other words, does the allegation of the violation in the complaint raise sufficient likelihood of future violation to justify issuing the injunction? If there is not sufficient basis to believe that an injunction is necessary, it would seem appropriate to dismiss the complaint even though a hearing on the merits of the charge is never reached. See SEC v. National Student Marketing Corp., 402 F. Supp. 641, 651-52 (D.D.C. 1975):

The ultimate question then presented is whether defendant's past conduct indicates that there is a reasonable likelihood that the wrong will be repeated. Neither the voluntary discontinuance of the activity, nor a declaration of an intention to comply with the law in the future will preclude an injunction. The Court must evaluate the sincerity of the defendant's assurances that he will not again transgress. The fact that the defendant maintains his innocence is a factor pointing to the need for an injunction. On the other hand, the detrimental consequences that may flow to an attorney as a result of an injunction and his subjective good faith in relying on the state of law as he then perceived it are factors which militate against the grant of injunctive relief.

Where the only basis for a claim of violation of the law is negligent conduct, it would seem that the need for injunctive relief is the weakest. On the other hand, the more deliberate the conduct, or the more frequent the violations, the greater the need for injunctive relief. See also SEC v. Frank, 388 F.2d 486, 490-93 (2d Cir. 1968)

(standards for issuance of a temporary injunction).

106. 402 F. Supp. 641 (D.D.C. 1975).

107. Id. at 650 . 
ney had prepared essentially all of the papers effecting the transaction, he could not ignore what he had learned when issuing his opinion letter later on:

[T]his Court rejects the proposition that a member of the bar can seek refuge behind a legal technicality, elevating form over substance, when he is party to and familiar with the circumstances which indicate that an illusory transaction is being undertaken which could be utilized to mislead third parties. [The lawyer's] focus on the narrow legal questions on which he opined is unrealistic in view of his participation in the total transaction which obviously had the possibility for misleading outsiders. ${ }^{108}$

In other cases, lawyers have been enjoined after having issued false statements while aware of facts which made it apparent that the statements made were without basis. ${ }^{109}$

The common denominator in these SEC enforcement decisions is an attorney's issuance of a statement which, in light of the facts as he or she knows them, simply is not justified. The duty imposed by these decisions is a linnited one. The attorney may not, in performing legal services, make a statement which is without basis in the context of the known facts. No case imposes a general duty to investigate the conduct of other parties to the transaction. But when, as a consequence of performing legal services, the lawyer becomes aware of facts which apparently contradict the premises underlying his or ler conclusions, continued adherence to those conclusions without investigation into the apparent contradiction inay expose the lawyer to enforcement proceedings. It is also interesting to note that although these decisions may speak of imposing liability under a negligence standard, the actionable conduct in each case went far beyond negligence and arguably was deliberate or intentional.

108. Id. at 648 (emphasis added).

109. SEC v. American Associated Systems, 482 F.2d 1040 (6th Cir. 1973), cert. denied, 414 U.S. 1130 (1974) (corporate counsel prepared quarterly reports, registration statement and prospectus, led discussion at shareholder meetings and in each instance concealed financial problems experienced by company, and made false statements as to business when he knew the truth); SEC v. Rega, [1975-1976 Transfer Binder] CCH FED. SEC. L. REP. II 95,222 (S.D.N.Y. 1975) (lawyer had represented to escrowee bank that conditions to payment of escrowed funds had been met when lawyer "had no basis whatsoever to make this representation and in fact his figures were erroneous at that"); SEC v. Century Investment Transfer Corp., [1971-1972 Transfer Binder] CCH FED. SEC. L. REP. If 93,232 (S.D.N.Y. 1971) (attorneys' exemption opinion went "beyond mere mistakes in legal judgment to constitute probable violations of the anti-fraud provisions of the securities laws"). See also SEC v. Frank, 388 F.2d 486, 489 (2d Cir. 1968). 
No enforcement case extends the attorney's duty beyond responsibility for matters relevant to his or her own work. Even where negligence is considered to be the proper standard, it is applicable only to the lawyer's handiwork; the anti-fraud provisions have not been used to impose responsibility for the accuracy of statements of others, at least where the lawyer is not actually on notice of their falsity. In this respect, the lawyer's duties under rule 10b-5 and section 17 are similar to those under section 11 involving the accuracy of the registration statement. In neither case does the attorney assume duties with respect to anything other than his or her own work.

That the anti-fraud provisions impose no general affirmative duty of diligence upon an attorney in connection with a securities issuance is given additional support by the Supreme Court's post-Hochfelder vacation and remand of the lower court's judgment in Sanders $v$. John Nuveen \& $\mathrm{Co}^{110}$ In that case, the Seventh Circuit had ruled that "an underwriter of short term commercial paper, who acted in the mistaken, but honest belief that the financial statements prepared by the certified public accountants correctly represented the condition of the issuer is liable to its customers for losses sustained as a result of the issuer's default."111 Without citing any statutory language to support its conclusion, the court of appeals reasoned that: "The underwriter is under a duty to make at least some investigation directed at the question whether the ever present possibility of fraud is in fact a reality."112 The Supreme Court summarily vacated the judgment and remanded the case for reconsideration im light of Hochfelder. ${ }^{113}$ Under Hochfelder, the failure to investigate another's actions or statements in the transaction, without more, is neutral conduct. The decision not to investigate becomes significant only when the putative investigator knows of fraudulent activity or of a misstatement or omission of a necessary material fact. In such a case the decision not to investigate but to conceal can itself become a direct violation of rule $10 \mathrm{~b}-5(1)$ or (3). In short, the result in Sanders is strong authority for the proposition that rule 10b-5 does not itself impose a "due diligence" requirement.

\section{Cases Involving Bond Counsel}

Very little authority directly discusses the obligations of bond counsel under the securities laws. There appear to be no reported ju-

110. 524 F.2d 1064 (7th Cir. 1975), vacated and remanded, 425 U.S. 929 (1976).

111. $524 \mathrm{~F} .2 \mathrm{~d}$ at 1066 .

112. Id. at 1071.

113. 425 U.S. 929 (1976). 
dicial decisions on point. Several SEC enforcement proceedings have named bond counsel but none contams substantial discussion of the legal theories. The most significant case concerned a Kentucky lawyer who, according to the SEC release, had not only served as bond counsel but had assumed principal legal responsibilities for reviewing the prospectus in a municipal issue. ${ }^{114}$ The case, brought by the SEC in an attorney disciplinary proceeding, was settled by a consent judgment. ${ }^{115}$ The SEC had found that the lawyer "willfully aided and abetted" violations of section 17(a) of the 1933 Act and section 10(b) of the 1934 Act because the lawyer, on the basis of information actually in his possession, "should have known, if he did not know, that the prospectus omitted material facts."116 The SEC's order would seem to have derived from the lawyer's additional undertaking to review the prospectus and the fact that he was fairly on notice as to misleading statements. It does not stand for the proposition that bond counsel generally has the duty to conduct a thorough investigation into the accuracy of all statements made in the offering circular.

It is interesting to note the curative steps which the lawyer's firm was required to take under the consent order. Among other matters, it was required to

. . . undertake an appropriate investigation in connection with acting as bond counsel including, among other things, obtaining independently audited financial statements and inquiring into the background of the various parties connected with the offering . . . [and to] require that it receive independently audited financial statements, representations from appropriate interested persons concerning the accuracy and completeness of the statements about them in any offering circulars, and a statement from counsel for any lessee or guarantor that such counsel has reviewed the offering circular and is aware of no inaccuracies therein. ${ }^{117}$

While this order clearly places the firm in the position of having to take affirmative steps to avoid involvement in fraudulent deals, it is noteworthy that the order does not require the firm to undertake a full examination of the accuracy of official statements similar to the examimation of prospectuses undertaken in registered offerings.

114. SEC v. Ferguson, SEC Litigation Release No. 5523 (Aug. 21, 1974). See also 17 C.F.R. $\$ 201.2(\mathrm{e})$ (1976) (allowing suspension or disbarment for willfully aiding and abetting a securities violation), discussed in note 69 supra.

115. Ferguson, SEC Litigation Release No. 5523.

116. The order found that:

Because of his review of the prospectus, his pre-existing relationship with the developer on other offerings of municipal bonds, and other factors which had come to his attention, respondent should have known, if he did not know, that the prospectus omitted material facts. Id.

117. Id. 
During 1976 the SEC has named bond counsel as defendants in two enforcement actions. It does not appear that any judgment concerning bond counsel has been entered in either of these cases. The accusations against bond counsel in these cases do not appear to be based on failure to undertake a due diligence examination as to facts stated in the official statement. In one involving fraudulent diversion of bond proceeds, the bond counsel was charged with rendering a negligently false opinion as to taxability and knowingly giving the issuer and a trustee incorrect advice concerning their duties to bondholders. ${ }^{118}$ In the other, the bond counsel is alleged to have made misrepresentations concerning his investigation of the validity of the issue and the basis of his legal opinion. ${ }^{119}$

In sum then, it would appear that not even an expansive reading of the cases under the anti-fraud sections would impose a general duty on bond counsel to examine the accuracy or completeness of the various representations in the official statement. On the other hand, if bond counsel should have actual notice of misleading statements in an official statement, continued participation as bond counsel could well constitute either a direct violation of rule $10 \mathrm{~b}-5$ or aiding and abetting another's violation.

Less certain of resolution is the situation in which bond counsel has neither actual notice of any misleading representation nor intention to deceive, but is, nonetheless, assertedly "on notice" of a violation. Under Hochfelder, the only possible private civil action under rule 10b-5 could arise when the defendant was reckless or wanton in disregarding actual evidence of a deceptive scheme or misleading representation. But if the negligence rule in Spectrum should prevail for SEC enforcennent actions, bond counsel could face an aiding and abetting claim premised on negligent performance of their services. Such a claim, however, would still have to be based on negligence in performing the services undertaken, and not on the general failure of bond counsel to conduct a due diligence investigation of the official statement.

\section{Duties in Practical Situations}

The remaining portion of this Article will examine, in practical terms, the effect of Hochfelder and existing enforcement cases on

118. SEC v. Astro Prods. of Kansas, Inc., SEC Litigation Release No. 7557 (Sept. 13, 1976).

119. SEC v. Reclamation Dist. No. 2090, SEC Litigation Release No. 7460 (June 22, 1976). 
municipal bond counsel's responsibilities and potential liabilities under the federal securities laws. While it may be concluded that bond counsel are not required to conduct a general investigation of the facts underlying the representations in the official statement (the sales "document used in municipal bond issues), ${ }^{120}$ difficult practical questions remain as to when bond counsel may be said to be placed "on notice" of securities law violations. If on notice, counsel may be in risk of an aiding and abetting violation under Spectrum if they give an approving opinion.

Two aspects of the problem deserve particular emphasis: the questions of what circumstances fairly put bond counsel on notice of a violation, and whether bond counsel is automatically on notice as to certain representations contained in the official statement.

\section{What Circumstances Place Bond Counsel} on Notice of Violations?

Two common situations illustrate problems that are likely to be faced by bond counsel. In one case, the bond counsel has no knowledge of any fraudulent scheme or of any misleading material representations in the official statement. Nonetheless, the bond counsel does not have reason to believe either that any lawyer expert in such matters has examined the official statement or that the underwriter has made a due diligence examination. While the reverse situation-where knowledgeable underwriter's counsel is involved-may be more comforting, it would still seem inappropriate that bond counsel should be placed "on notice" for failing to require that a knowledgeable lawyer conduct a thorough due diligence investigation. Even in registered financings, there is no statutory obligation that any lawyer do more than give an opinion as to the legality of the securities. Failure to require reasonable investigation of an official statement by outside lawyers or by the purchaser is not in itself a securities violation. There is a violation only if the official statement is in fact misleading. Unless there is some evidence that the statement is misleading, bond counsel has no obligation to conduct or procure a reasonable investigation.

A somewhat more difficult and not wholly uncommon situation arises when the bond counsel knows of no misleading statements in the official statement but, as a knowledgeable securities lawyer, would become aware upon review that the statement is less thorough than is cus-

120. See text accompanying note 18 supra. 
tomary. Once again, however, bond counsel should not be considered as being on notice of any possible violation. It is not a violation for an official statement to be brief or even to omit important matters unless such omissions make the statement misleading. To be on notice of a violation, counsel must be on notice of either the falsity of the representations or the omission of facts needed to make the representations not misleading. It is not sufficient simply to know that potentially relevant facts are omitted.

These two examples are very important in determining the extent of bond counsel's responsibility. If bond counsel were to be on notice of violations simply because certain other parties did not investigate thoroughly or because disclosure was less thorough than customary, they would be required in nearly every issue to insure that the disclosure at least met their own standards of completeness and that it had been subjected to expert legal review. This would make bond counsel generally responsible for the official statement. Whether or not this is good public policy, and it may well be that it is not, ${ }^{121}$ it is not mandated by the federal statutes or the present case law.

\section{The Official Statement}

There would appear to be certain aspects of the official statement for which bond counsel may quite arguably be held to be on notice of material misstatements. The official statement will almost always contain a brief description of the legal opinion, the terms of the bonds, and the provisions of certain underlying documents. While it may be suggested that bond counsel has no duty to review the official statement, it would not seem wholly unlikely, at least where a bond counsel has had the opportunity to review the official statement, for a court to conclude that the job of giving the opinion includes ascertaining that the client's public representations about bond counsel's work are accurate. ${ }^{122}$ Thus, the descriptions of the nature of the legal opinion,

121. Two important factors militate against requiring bond counsel to be generally responsible for official statements. First, such a requirement would force a bond counsel firm to act as an expert in an area where it may have little or no expertise. Other professionals are already involved in the municipal bond transaction who have the expertise to engage in the kinds of investigations which would be necessary to insure the completeness and accuracy of the official statement.

Second, the reliance of investors on their underwriters and of the underwriters and investors on certified public accountants makes it more reasonable to place the requirement of due diligence investigation on these professionals. The substantial costs of placing any duty to investigate the completeness of official statements on bond counsel also argue against such a result.

122. This would seem particularly appropriate where the issuer causes an official 
of the terms of the bonds, and of the authorizing documents are all matters which it would be imprudent for counsel to ignore. The danger, of course, is that an attorney could be accused of negligence or recklessness in allowing his or her own work product to be misrepresented by the description.

It may seem obvious to suggest that bond counsel may be held to be on notice as to the accuracy of the official statement's description of its own legal opinion. However, in many official statements the description of bond counsel's opinion is open to a much broader reading than the opinion itself. It is not uncommon, for example, for official statements to state that all legal matters incident to the authorization and issuance of the bonds are subject to bond counsel's approval. Such language does not make clear the nature of the opinion. Of course, since the text of the legal opinion is commonly printed on the bond itself, it might be difficult to contend that a bondholder could be misled. Nonetheless, vague or overly broad descriptions of the services performed by bond counsel may tend to mislead purchasers as to the limited scope of the opinion. ${ }^{123}$ Unless they are willing to undertake an examination as broad as the description of the opinion presented in the official statement, bond counsel would be well advised to seek to avoid such expansive descriptions of their services.

It would, indeed, seem more prudent for bond counsel to require issuers preparing official statements to describe the proposed legal opinion by stating both the limited nature of the examination to be undertaken and the substance of the opinion. It may also be advisable to follow the practice of some counsel who add, to the extent that it is true, that bond counsel has not examined and will not opine as to the accuracy or completeness of the official statement except as to the summary of the terms of the bonds and of the principal transcript documents. ${ }^{124}$

statement to be prepared. In representing the issuer, bond counsel may be less obliged to review an official statement that is prepared by the bord purchasers without the bond counsel's participation. And as to selling papers prepared by purchasers other than the representatives of the underwriter or by secondary market traders, bond counsel would necessarily be without any responsibility since they have little control.

123. In SEC v. Reclamation Dist. No. 2090, SEC Litigation Release No. 7460 (June $22,1976)$, the SEC appears to have charged bond counsel with misrepresentation and omissions concerning the lawyer's investigation and the basis upon which the legal opinion was issued.

124. Statutory liability for misrepresentations in prospectuses cannot be disclaimed and to attempt such a disclaimer may be misleading. SEC Release No. 33-3411, 2 CCH FED. SEC. L. REP. II 25,095 (1951). This would not, however, appear to prohibit counsel from stating the limited nature of an investigation. 
Bond counsel may also be considered on notice of misstatements in the official statement which concern the terms of the bonds themselves or the authorizing ordinance or indenture, since these are instruments which are normally drafted or at least closely examined by bond counsel. If these parts of the official statement appear on their face to be wrong or to omit matters required to make them not misleading, bond counsel might find it similarly difficult to argue that it was not on notice as to such inaccuracies.

The question of whether bond counsel could be held on notice as to other representations in the official statement which are questionable on their face is more difficult. Must bond counsel review all statements in the official statement to see if they are consistent with his or her understanding of the situation? Obviously, no clear answer can be given. Such an exammation is beyond the scope of the bond counsel's work and may well concern matters not within a lawyer's competence. Bond counsel are not generally responsible for representations in an official statement which they did not draft and are not employed to investigate. Moreover, no case holds that any such duty exists. In the case of a registered security, the 1933 Act does not impose the liability of an expert on lawyers other than as to the referenced legal opinions. It is therefore reasonable to argue that bond counsel has no duty to examine other representations in the official statement.

The risk remains, nonetheless, that the lawyer could be accused of closing his or her eyes to violations in choosing not to review the official statement for facial inaccuracies. Prudent counsel should therefore review the official statement to see if it gives any clear notice on its face of material misrepresentations. ${ }^{125}$ Once again, it is important to distinguish such a facial review from a due diligence investigation of the facts underlying representations made in the official statement.

As a result of consultations with the issuer, bond counsel may on occasion become aware of matters which require disclosure. In such a case, the lawyer would have an obligation to advise the client of this requirement and to review the official statement for compliance.

In considering what places a lawyer on notice of violations, one must keep in mind that the cases suggest a rather rigorous test as to notice. Injunctions have been entered against lawyers only where there were strong indications of actual knowledge of facts suggesting the fraudulent nature of the scheme. Of course, there are limits to the extent to which this analysis may prevail. An official statement 
may well be so poorly constructed, or so wholly incomplete, that it will appear misleading on its face. While it will undoubtedly be difficult to decide when this is the case, bond counsel should attempt to avoid giving an approving opinion where he or she has reviewed an official statement on its face and found it to be so imsufficient as to be likely to mislead.

\section{CONCLUSION}

Historical development has created a umque role for bond counsel in municipal securities transactions. As special counsel in a municipal issue, bond counsel have only a limited responsibility: they opine only as to the validity and tax-exempt status of the mumicipal securities under consideration. Given this narrow responsibility, the securities laws do not require bond counsel to conduct a general due diligence investigation of non-legal matters included in a municipal security official statement. While as a matter of prudence bond counsel nray require an official statement to summarize their own work accurately, they should not be held responsible for a due diligence-type investigation of the statement or for policing the accuracy of its representations. In short, the securities law duties of bond counsel do not extend beyond responsibilities for matters relevant to the specific work for which they are retained. 